\title{
Jigsaw IV Tekniği Kullanımının Fen Öğretiminde Öğrencilerin Motivasyon, Fen Kaygısı ve Akademik Başarılarına Etkisi
}

\author{
The Effects of employing the Jigsaw IV Technique in Science and Technology \\ Education upon Students' Motivation, Science Anxiety and their Academic Achievement
}

\begin{abstract}
Mustafa DOĞRU* Sila ÜNLÜ**

Özet: Bu çalışmada işbirlikli öğrenme yöntemlerinden Jigsaw IV tekniğinin öğrenci motivasyonu, fen kaygısı ve akademik başarısına etkisi araştırılmıştır. Araştırma, 2011-2012 öğretim yılında 4 hafta süreyle, Antalya İli, Konyaaltı ilçesi MEB’ye bağlı Konyaaltı İlköğretim Okulu'nda öğrenim gören 64 yedinci sınıf öğrencisinin katılımıyla gerçekleşmiştir. Araştırmanın amacına uygun olarak çalışmada ön test-son test kontrol gruplu yarı deneysel desen kullanılmıştır. Araştırma "Yaşamımızdaki Elektrik" ünitesi kapsamında yürütülmüştür. Deney grubuna Jigsaw IV tekniği, kontrol grubuna ise geleneksel öğretim yöntemleri uygulanmıştır. Çalışmada veriler, "Fen Ögrenimine Yönelik Motivasyon Ölçeği”, "Fen Kaygl Ölçeği" ve "Akademik Başarı Testi” ile toplanmıştır. Elde edilen veriler, SPSS istatistik programı kullanılarak analiz edilmiştir. Elde edilen bulgulara göre, deney ve kontrol gruplarının motivasyon, fen kaygısı ve akademik başarı ön test ve son test puanları arasında istatistiksel olarak bir farkın olduğu tespit edilmiştir. Geleneksel yöntemle işlenen derste katılımcıların sadece akademik başarılarının arttığı belirlenirken, Jigsaw IV tekniği ile işlenen derste ise katılımcıların kaygısının azaldığı ve akademik başarısının arttığı saptanmıştır.
\end{abstract}

Anahtar Sözcükler: Jigsaw IV, motivasyon, fen kaygısı, fen öğretimi, işbirlikli öğrenme

Abstract: This study records the results of employing the Jigsaw IV technique, one of the cooperative learning methods, on student motivation, science anxiety and their academic success. The study was conducted during the 2011-2012 academic year over four weeks; with the participation of $647^{\text {th }}$ grade students who receive education at Konyaaltı Elementary School affiliated to MEB in Antalya. Conforming to the purpose of this study, a pre test-post test quasi-experimental design with a control group was employed in this study. The study was conducted within the scope of the unit called "Electricity in Our Lives". The Jigsaw IV technique was applied to the experimental group, while traditional teaching methods applied to the control group. The data was collected in the, "Students Motivation towards Science Learning Questionnaire", the "Science Anxiety Scale" and the "Academic Success Test”. It was analyzed with the SPSS statistics program. It was found there was a statistical difference between motivation, science anxiety and academic success in the pre test and post test scores of the experiment and control groups. Only the academic success of participants increased when taught with the traditional method; while the anxiety of participants decreased and academic success increased in the lesson which was taught with the Jigsaw IV technique.

Keywords: Jigsaw IV, motivation, science anxiety, science teaching, cooperative learning

\footnotetext{
* Yrd. Doç. Dr., Akdeniz Üniversitesi, Eğitim Fakültesi, İlköğretim Bölümü, Antalya, mustafadogru@akdeniz.edu.tr

** Akdeniz Üniversitesi, Eğitim Fakültesi, İlköğretim Bölümü, Antalya, silaunlu@akdeniz.edu.tr
} 
Öğrenci merkezli eğitim anlayışı ile birlikte öğrencilerin nasıl en iyi şekilde öğrenebilecekleri önemli araştırma konuları arasında yer almıştır. Bu bağlamda öğrencinin öğrenme sürecinde sorumluluğu üzerine aldığı aktif öğrenme uygulamaları sıkça araştırmalara konu olmaktadır (Sivan, et. alii, 2000; Kalem, \& Fer, 2003; Aydede, \& Matyar, 2009). Aktif öğrenme uygulamaları, öğrencinin ders içinde etkin olarak uygulamalarda bulunduğu, öğrenciyi düşünmeye zorladığ ve bilgiyi kendisinin yapılandırmasına firsat verdiği yaklaşımları içerir (Açıkgöz, 2006, 17). Bütün bu süreçte öğrencinin diğer öğrencilerle ve öğretmenle birebir iletişimi ve etkileşimi ön plandadır (Özel, 2004). İşbirliğgine dayalı öğrenme yaklaşımı da öğrencilere bu ortamı sağlayan aktif öğrenme yaklaşımlarından biridir.

İşbirliğine dayalı öğrenme, öğrencilerin heterojen gruplar halinde yardımlaşma ve aktif katılıma teşvik edildiği; grupların kendi öğrenmelerini yapılandırdığı problem tabanlı bir öğrenme yaklaşımıdır (Johnson, Johnson, \& Smith, 1998). Bir başka değişle işbirliğine dayalı öğrenme, geleneksel öğrenme ortamlarında göz ard1 edilen öğrenciler arası iletişimi ve aktif katılımı temeline almıştır. Geleneksel öğretim ortamlarında öğrenciler daha çok yarış ve rekabet içerisindedir. Ancak işbirliğine dayalı öğrenmede durum bunun tam aksi olup bu öğrenme şekli öğrencilerde olumlu bağımlılık sağlayarak, öğrencilere birbirlerini çalışmaya teşvik etme, öğrenmelerine yardımcı olma ve birbirlerinin öğrenmelerinden sorumlu olma görevleri verir (Thousand, Villa, \& Nevin, 2009). Johnson, D. W., \& Johnson, R. T. (1975)'ye göre, işbirliğine dayalı öğrenmenin dört temel öğesini, karş1lıklı bağl1lık oluşturarak amaca ulaşmak için dayanışmada bulunmak, öğrenciler arası yüz yüze iletişim, uzmanlaşma için bireysel sorumluluk taşıma, kişiler ve gruplar arası grup becerilerinin uygun kullanımı olarak tanımlanmıştır. $\mathrm{Bu}$ noktada öğretmenin rolü ise, işbirliğine rehberlik ederek bu koşulların oluşması için gerekli ortamı yaratmaktır (Demirel, 2008).

İşbirlikli öğrenme yöntemi uygulanma noktasında birden fazla teknik içermektedir. Bu teknikler grupların oluşturulması ve genel amaçları bakımından benzerlik gösterse bile uygulanan ders ve sınıfın düzenlenmesi bakımından birbirlerinden ayrılır. Bu tekniklerden biri de alan yazınında ayrılıp-birleş tekniği olarak da geçen Jigsaw tekniğidir. Jigsaw tekniği, öğrenmeye yardımcı olmak amacıyla öğrencilerin birbirlerinden öğrenmesine olanak sağlayan küçük grup etkinliklerini kapsayan bir tekniktir (Heeden, 2003). Jigsaw tekniği; giriş, uzman araştırması, rapor hazırlama ve yeniden biçimlendirme, tamamlama ve değerlendirme olmak üzere dört ana basamaktan oluşmaktadır ve uygulama süreci de oldukça esnektir (Şimşek, 2007). 1970'lerin sonlarında Aronson ve arkadaşları tarafından geliştirilen Jigsaw tekniği, uygulama basamaklarındaki farklı1ıklar bakımından çeşitlenmektedir (Özkıdık, 2010). 1990'ların sonunda Holliday tarafından geliştirilen Jigsaw IV tekniği ise girişte konuya dikkat çekmek amaciyla etkinlik yapılması ile başlar. Uzman grup ve asıl grup çalışmalarının ardından iki ayrı mini sınav yapılması bakımından diğer Jigsaw tekniklerinden ayrılır (Holliday, 2002).

Yapılan araştırmalar Jigsaw tekniğinin öğrenci başarısını artırmada geleneksel öğretim yöntemlerine göre daha etkili olduğunu, öğrencilerin fikirlerini açıklama konusunda cesaretlendiklerini, kendilerine olan güveni artırdığını ve birbirleri arasında işbirliği yapmaya yönlendirdiğini göstermektedir (Aksoy, 2006; Doymuş, \& Şimşek, 2007, \& Buzludağ, 2010). Aynı zamanda, öğrencilerin Jigsaw teknikleri ile aldıkları derslerde ortak hedef doğrultusunda işbirliği ile çalışmanın bir sonucu olarak birbirlerini motive ettikleri ortaya konulmuştur (Anderson, \& Palmer, 1988; Kılıç, 2008). Ancak Jigsaw tekniklerinin motivasyon üzerinde etkisi olmadığını ortaya koyan çalışmalar da bulunmaktadır (Shackar, \& Fischer, 2004; Ayna, 2009). Çünkü diğer eğitim disiplinlerinde de olduğu gibi fen eğitiminde öğrenci motivasyonu, öğretmen ve öğrenci ilişkilerinden, bireysel farklılıklardan, derste uygulanan öğretim yöntem ve tekniklerinden, yaratılan sınıf atmosferinden etkilenmektedir (Yılmaz, \& Çavaş, 2007). Ayna (2009)'nın yaptığı çalışmada Jigsaw tekniklerinin öğrencilerin iş yükünü artırarak ders sürecinde öğrenciyi zorladığg ve 
bu nedenle öğrencilerin kaygı düzeylerinin artarak motivasyonun olumsuz etkilenmiş olabileceğine dikat çekilmiştir.

Motivasyon, bireyde kasıtlı ya da kasıtlı olmayarak davranışı meydana getiren ve yine birey tarafından amaçlı olarak tekrarlanmamasına karar veren güdülerin tümü olarak tanımlanmaktadır (Arık, 1996). Kaygı ise; üzüntü, sıkınt1, korku, başarısızlık duygusu, acizlik, yargılanma gibi heyecanların birini veya birçoğunu içerebilen, sonunun ne olduğunu bilmeksizin duyduğumuz belli belirsiz bir korku olarak tanımlanmaktadır (Ünlü, 2001, 92). Jigsaw tekniğinin kimya öğrencilerinin ders kaygısı düzeylerine etkisini araştırmak üzere yapılan bir çalışma, bu tekniğin bireylerin fen kaygı düzeylerini azalttığını göstermektedir (Oludipe, \& Awokoya, 2010). Bunun yanında işbirlikli öğrenme tekniklerinin, öğrencilerin farklı derslere yönelik etkisini inceleyen çalışmalar da, bu tekniklerin öğrenci kaygı düzeyini azalttığını göstermektedir (Senemoğlu, 2011, 499).

Bu araştırmanın amacı, 7. sınıf Fen ve Teknoloji dersi, "Yaşamımızdaki Elektrik" ünitesinin öğretilmesinde, geleneksel öğretim yönteminin uygulandığı kontrol grubu ile Jigsaw IV tekniğinin kullanıldığı deney grubu öğrencilerinin fen öğrenmeye yönelik motivasyonun, fen kaygısı ve fen dersi başarıları düzeyleri arasında anlamlı bir fark olup olmadığını incelemektir. Bu amaçla aşağıdaki alt problemlere cevap aranmıştır:

1) Deney ve kontrol grubu öğrencilerinin "Fen Öğrenimine Yönelik Motivasyon Ölçeğgi”, “Fen Kaygl Ölçeğì” ve Yaşamımızdaki Elektrik Ünitesi Akademik Başarı Testi” ön test puanları arasında anlamlı bir fark var midir?

2) Deney ve kontrol grubu öğrencilerinin "Fen Öğrenimine Yönelik Motivasyon Ölçeği”, "Fen Kaygı Ölçeğì" ve "Yaşamımızdaki Elektrik Ünitesi Akademik Başarı Testi" son test puanları arasında anlamlı bir fark var midır?

3) Deney grubu öğrencilerinin "Fen Öğrenimine Yönelik Motivasyon Ölçeği”, "Fen Kaygı Ölçeği " ve "Yaşamımızdaki Elektrik Ünitesi Akademik Başarı Testi”" ön test-son test puanları arasında anlamlı bir fark var midır?

4) Kontrol grubu öğrencilerinin "Fen Öğrenimine Yönelik Motivasyon Ölçeği”,, "Fen Kaygı Ölçeği" ve "Yaşamımızdaki Elektrik Ünitesi Akademik Başarı Testi" ön test-son test puanları arasında anlamlı bir fark var midır?

\section{YÖNTEM}

\section{Araştırmanın Modeli}

Deneme modelinin uygulandığ mıştır. Birbirine denk olan şubelerden yansız atama yoluyla bir deney bir de kontrol grubu belirlenmiş̧tir. Deney grubunda konular Jigsaw IV tekniği ile işlenirken, kontrol grubunda aynı konu geleneksel öğretim yöntemlerinden faydalanılarak işlenmiştir. Her iki gruba deney öncesi ön test, deney sonrasında son test uygulanmıştır (Büyüköztürk, 2006).

\section{Çalışma Grubu}

Araştırma, 2011-2012 öğretim yılında 4 hafta süreyle, Antalya İli Konyaaltı İlçesi, MEB'e bağlı Konyaaltı İlköğretim Okulu'nda öğrenim gören 64 yedinci sınıf öğrencisinin katılımıyla gerçekleşmiştir. Yansız atamayla belirlenen deney grubuna ( $\mathrm{N}=30)$ Jigsaw IV tekniği, kontrol grubuna $(\mathrm{N}=34)$ ise geleneksel öğretim yöntemi uygulanmıştır. Deney grubu 18 erkek ve $12 \mathrm{kız}$, kontrol grubu 20 erkek ve 14 kız öğrenciden oluşmaktadır. Her iki grubun deney öncesi grup denkliğinin sağlanması amacıyla aynı dönem yapılmış olan yazılı yoklama sonuç puanları üzerinden $t$ testi analizi yapılmış ve grupların denk olduğuna dair analiz sonuçları Tablo 1'de sunulmuştur. 
Tablo 1. Deney ve Kontrol Grubu Denkliğine İlişkin Öğrencilerin Yazılı Yoklama Sonuç Puanlar1 $t$-testi

\begin{tabular}{|c|c|c|c|c|c|c|}
\hline & $\mathbf{N}$ & $\bar{X}$ & $\mathbf{S}$ & sd & $\mathbf{t}$ & $\mathbf{p}$ \\
\hline $\begin{array}{l}\text { Deney } \\
\text { Grubu }\end{array}$ & 30 & 71.60 & 21.4 & \multirow{2}{*}{62} & \multirow{2}{*}{0.75} & \multirow{2}{*}{0.45} \\
\hline $\begin{array}{c}\text { Kontrol } \\
\text { Grubu }\end{array}$ & 34 & 75.38 & 19.06 & & & \\
\hline
\end{tabular}

Tablo 1 incelendiğinde deney grubu ile kontrol grubu birinci yazılı sınav sonuç puanları arasında 0.05 düzeyinde anlamlı bir farkın olmadığı tespit edilmiş ve deney öncesi grupların denk olduğu belirlenmiştir $(\mathrm{p}<0.05)$.

\section{Veri Toplama Araçları}

Çalışmada öğrencilerin fen öğrenimine yönelik motivasyon düzeylerini, fen dersine karşı kayg1 düzeylerini ve yaşamımızdaki elektrik ünitesine yönelik fen başarılarını belirlemek amacıyla "Fen Öğrenimine Yönelik Motivasyon Ölçeğì", "Fen Kaygl Ölçeğì" ve "Yaşamımızdaki Elektrik Ünitesi Akademik Başarı Testi" veri toplama aracı olarak kullanılmıştır.

\section{Fen Öğrenimine Yönelik Motivasyon Ölçeği (FÖYMÖ)}

Araştırmada kullanılan “Students' Motivation Toward Science Learning (SMTSL)" ölçeği Tuan, Chin ve Shieh tarafindan 2005 yllında geliştirilmiş̦tir. "Fen Öğrenimine Yönelik Motivasyon Ölçeğil" nin geçerlik ve güvenirlik çalışmaları Yılmaz ve Çavaş (2007) tarafından yapılmıştır. Ölçeğinin orijinal formu 9'u negatif, 26'sı pozitif olmak üzere toplamda 35 maddeden oluşmaktadır. Geçerlik ve güvenirlik çalışması sonucu ise ölçeğin son hali 8'i negatif ve 25'i pozitif olmak üzere toplamda 33 maddeden oluşmuştur. Ölçek "Hiç Katılmıyorum" ile "Tamamen Katılıyorum" arasında 5'li likert tipindedir. Ölçeğin güvenirlik katsayısı (Cronbach Alfa) ise 0.87'dir.

\section{Fen Kaygı Ölçeği (FKÖ)}

Araştırmada kullanılan fen ve teknolojiye yönelik kaygı ölçeği Güzeller, \& Doğru (2011) tarafından geliştirilmiştir. "Fen Kaygl Ölçeği sahiptir. Ölçeğin Cronbach Alpha İç Tutarlılık Güvenirlik Katsayısı birinci faktör için 0.77, ikinci faktör için 0.942 olmak üzere toplam katsayısı 0.964'tür. Beşli likert tipindeki ölçekte bulunan kaygı için olumlu maddeler "kesinlikle katılmıyorum" ifadesinden "kesinlikle katıllyorum" ifadesine doğrudur. Olumlu maddelere 1'den 5'e; olumsuz maddeler için ise 5'ten 1'e şeklinde puanlar verilerek sonuçlar değerlendirilmiştir.

\section{Yaşamımızda Elektrik Ünitesi Akademik Başarı Testi (YEÜABT)}

Bu test öğrencilerin yaşamımızdaki elektrik ünitesini anlama düzeylerini belirlemek amaciyla Özkıdık (2010) tarafından hazırlanmıştır. Özkıdık test maddelerinin hazırlanmasında 7. sınıf yaşamımızdaki elektrik ünitesi kazanımlarını göz önüne almış ve yapmış olduğu geçerlik ve güvenirlik çalışmaları sonucunda 25 maddelik teste son halini vermiştir. Testin güvenirliği ise $\mu=0,8175$ olarak tespit edilmiştir.

\section{Verilerin Analizi}

Araştırmada deney ve kontrol gruplarının belirlenen değişkenler yönünden puanları arasındaki farklılı̆̆ saptamak amacıyla, araştırılan değişkenlerin istatiksel analizleri SPSS programı kullanılarak " $t$-testi" ile değerlendirilmiştir. Bu analiz tekniği, iki ortalama arasındaki farkları test etmede kullanılan parametrik bir tekniktir. En çok uygulamalar "bağımsız gruplar" ya da "bağımlı gruplar" arasındaki farkı test etmek üzere yapılan t-testleri üzerine yapılır (Büyüköztürk, 2006). 


\section{Uygulama}

Uygulamadan önce öğrencilerin aynı döneme ait fen ve teknoloji dersi yazılı yoklama sonuç puanlarından yola çıkarak grup denkliği test edilmiş ve rastgele deney-kontrol grupları belirlenmiştir. 7. sınıf "Yaşamımızdaki Elektrik Ünitesi”, Fen ve Teknoloji öğretim programına bağlı kalınarak 4 hafta; 16 ders saati içerisinde planlanmıştır. Deney grubunda Jigsaw IV tekniğinin uygulama basamaklarının takip edildiği ders planı işlenirken, kontrol grubunda geleneksel ögretim yöntemine uygun ders işlenmiştir.

Jigsaw IV tekniğinin uygulandığ deney grubunda, Jigsaw (asıl) grupların oluşturulmasında grupların kendi içinde benzeşik olmayıp; diğer gruplar arasında değişkenler açısından denkliğinin sağlanması amacıyla öğrencilerin daha önceki sınav notlarını kullanarak bir başarı listesi oluşturulmuştur (Slavin, 1991). 30 kişilik olan deney grubunda altışar kişilik beş adet Jigsaw (asıl) grup oluşturulması planlanmıştır. Ardından, başarı sırasına göre dizili öğrenci listesinde, birinci sirada olandan başlanarak; 1. grup, 2. grup, 3. grup, 4. grup, 5. grup olmak üzere ilk beş ögrenciye, bir sonraki beş ögrrenciye ise 5. grup, 4. grup, 3. grup, 2. grup, 1. grup şeklinde numara verilmiştir. Bu işlem bütün öğrencilere numara verilene kadar devam etmiş ve sonunda başarı sıralamasındaki 1. ve 10. sıradaki öğrenciler aynı grupta yer alırken; 2. ve 9. sıradaki öğrenciler de aynı grupta yer almıştır. Dört haftalık ders konuları planlanırken, her bir ders planı altı alt başlı̆ga bölünerek oluşturulmuştur. Bu sayede her bir ders planı için, altı alt başlık Jigsaw gruplarına tanıtılmış ve grupların belirlediği grup başkanı önderliğinde grup üyelerine dağıtılmıştır. Bu paylaşım sonunda bir Jigsaw grubu içindeki her bir öğrenci birbirinden farklı bir konuyu almıştır. Ardından, farklı Jigsaw grubunda olup aynı konuyu alan öğrenciler bir araya gelerek, o konu üzerinde ayrıntılı bilgi edinmiş̧tir (Tablo 2).

Tablo 2. Jigsaw (Asıl) ve Uzman Gruplarının Oluşturulması

\begin{tabular}{|c|c|c|c|c|c|c|}
\hline \multicolumn{9}{|c|}{ Jigsaw (asıl gruplar) } \\
\hline Konular & Uzman Gruplar & 1. Asıl Grup & 2. Asıl Grup & 3. Asıl Grup & 4. Asıl Grup & 5. Asıl Grup \\
\hline 1. Konu & 1. Uzman Grup & 1. öğrenci & 9. öğrenci & 28. öğrenci & 7. öğrenci & 5. öğrenci \\
\hline 2. Konu & 2. Uzman Grup & 10. öğrenci & 12. öğrenci & 13. öğrenci & 24. öğrenci & 16. öğrenci \\
\hline 3. Konu & 3. Uzman Grup & 11. öğrenci & 29. öğrenci & 3. öğrenci & 27. öğrenci & 25. öğrenci \\
\hline 4. Konu & 4. Uzman Grup & 20. öğrenci & 19. öğrenci & 8. öğrenci & 4. öğrenci & 26. öğrenci \\
\hline 5. Konu & 5. Uzman Grup & 21. öğrenci & 2. öğrenci & 23. öğrenci & 17. öğrenci & 16. öğrenci \\
\hline 6. Konu & 6. Uzman Grup & 30. öğrenci & 22. öğrenci & 18. öğrenci & 14. öğrenci & 6. öğrenci \\
\hline
\end{tabular}

Jigsaw IV tekniğini diğer Jigsaw uygulamalarından ayıran ilk fark, konu dağılımından önce öğretmenin konuya dikkat çekmek ve öğrencilerde farkındalık uyandırmak amacıyla konuyla ilgili özet konu anlatımının, video gösteriminin ya da konuya yönelik bir etkinliğin öğretmen tarafından uygulanmasıdır (Holliday, 2000). Bu çalışmada giriş aşamasında, konu ile ilgili kavram ve genellemeleri açıklayan 15 dakikalık çizgi filmler izletilmiştir.

Giriş aşamasının ardından, diğer Jigsaw tekniklerinde de olduğu gibi konu dağılımları yapılmış ve aynı konuyu alan öğrenciler bir araya gelerek uzman grupları oluşturulmuştur. Uzman gruplar konularına ait araştırma yapmış ve konuları ile ilgili onlara verilen etkinlikleri yerine getirmişlerdir. Ardından, Jigsaw IV tekniğini diğer Jigsaw tekniklerinden ayıran uzman grup mini sınavları uygulanmıştır. Bu basamakta amaç, uzman grupların kazanımları edinme 
derecesini belirlemek, eksik ve yanlış öğrenmelerin önüne geçmek olmuştur (Şimşek, 2007). Gerekli düzeltmelerin yapılması ve geri dönüşlerin sağlanmasının ardından öğrenciler Jigsaw (asıl) gruplarına geri dönerek, diğer Jigsaw tekniklerinde de olduğu gibi; her öğrenci kendi uzmanlık konusunu diğer grup arkadaşlarına anlatmıştır. Böylece bütün konu başlıkları, uzman öğrencilerce akranlarına anlatılmıştır.

Bu aşamanın ardından Jigsaw IV tekniğini diğer tekniklerden ayıran üç aşama gelmektedir. Bütün konuların anlatılmasının ardından, Jigsaw (asıl) gruplarında kazanımların sağlanıp sağlanmadığının ölçülmesi için bütün konuları kapsayan ikinci bir mini sınav daha yapılmış ve bu sınavın ardından da yanlış öğrenmeler düzeltilmiş ve eksiklikler tamamlanmıştır.

$\mathrm{Bu}$ aşamaların ardından bütün sınıf ile genel değerlendirme yapılması amacıyla etkinlik kitabındaki etkinliklerden faydalanılmıştır. Ardından bireysel değerlendirme yapılması amacıyla tüm konuyu kapsayan test öğrencilere uygulanmıştır. Bu uygulama sonrasında öğrencilerin elde ettiği puanlar, diğer aktivitelerden alınan puanlarla birlikte süreç sonundaki öğrenci performansını belirlemek için kullanılmıştır.

Kontrol grubuna uygulanan geleneksel öğretim yönteminde ise düz anlatım ve soru-cevap tekniğine yer verilmiştir. Ünitedeki konular belli bir sıra ve düzen içerisinde öğretmen tarafından anlatılmıştır. Anlatım esnasında ve anlatım bitiminde konu hakkında çeşitli sorular sorulmuş ve cevapları alınmıştır. Soru-cevap esnasında verilen cevaplar sınıf ortamında tartışılmış ve değerlendirilmiştir. Ders sürecinde öğretmenin anlaşılmadığını düşündüğü konular yine düz anlatım şeklinde öğretmen tarafından özetlenmiştir.

\section{Bulgular}

Araştırma sonucunda elde edilen bulgular 6 alt problem başlığında incelenmektedir. Bulgular tablolar halinde verilmiştir.

Tablo 3'te katılımcilardan deney grubu ve kontrol grubu öğrencilerin YEÜABT, FKÖ, FÖYMÖ ön testlerinden aldıkları puanların "t-testi" analiz sonuçları verilmiştir.

Tablo 3. Deney ve Kontrol Grubundaki Öğrencilerin YEÜABT, FKÖ, FÖYMÖ Ön Test Puanlarına İlişkin t-testi Sonuçları

\begin{tabular}{|c|c|c|c|c|c|c|c|}
\hline & & $\mathrm{N}$ & $\bar{X}$ & $\mathrm{~s}$ & sd & $\mathrm{t}$ & $\mathrm{p}$ \\
\hline \multirow{2}{*}{ Motivasyon } & Deney Grubu & 30 & 1.24 & 14.9 & \multirow{2}{*}{62} & \multirow{2}{*}{0.04} & \multirow{2}{*}{0.96} \\
\hline & Kontrol Grubu & 34 & 1.24 & 13.2 & & & \\
\hline \multirow{2}{*}{ Kaygı } & Deney Grubu & 30 & 56.6 & 25.3 & \multirow{2}{*}{62} & \multirow{2}{*}{0.38} & \multirow{2}{*}{0.70} \\
\hline & Kontrol Grubu & 34 & 59.3 & 30.7 & & & \\
\hline \multirow{2}{*}{ Başarı } & Deney Grubu & 30 & 9.33 & 3.00 & \multirow{2}{*}{62} & \multirow{2}{*}{1.53} & \multirow{2}{*}{0.13} \\
\hline & Kontrol Grubu & 34 & 8.09 & 3.42 & & & \\
\hline
\end{tabular}

$\mathrm{p}>0.05$

Tablo 3 incelendiğinde, deney ve kontrol gruplarının YEÜABT, FKÖ, FÖYMÖ ön test puanları arasında anlamlı bir farkın olmadığ 1 belirlenmiştir ( $>0.05$ ). Bu bulguya göre, deneysel işlem öncesinde, deney ve kontrol gruplarının üç değişken açısından da benzer oldukları görülmektedir. Uygulama öncesinde öğrencilerin belirlenen değişkenler açısından birbirlerine benzer olmaları, uygulanan öğretim yönteminin etkililiğinin belirlenmesi bakımından amacına uygundur.

Tablo 4'te katılımcılardan deney grubu ve kontrol grubu öğrencilerinin YEÜABT, FKÖ, FÖYMÖ son testlerinden aldıkları puanların "t-testi" analiz sonuçları verilmiştir. 
Tablo 4. Deney ve Kontrol Grubundaki Öğrencilerin YEÜABT, FKÖ, FÖYMÖ Son Test Puanlarına İlişkin t-testi Sonuçları

\begin{tabular}{|c|c|c|c|c|c|c|c|}
\hline & & $N$ & $\bar{X}$ & $s$ & $s d$ & $t$ & $p$ \\
\hline \multirow{2}{*}{ Motivasyon } & Deney Grubu & 30 & 1.27 & 18.7 & \multirow{2}{*}{62} & \multirow{2}{*}{0.18} & \multirow{2}{*}{.87} \\
\hline & Kontrol Grubu & 34 & 1.26 & 20.7 & & & \\
\hline \multirow{2}{*}{ Kaygı } & Deney Grubu & 30 & 48.1 & 23.1 & \multirow{2}{*}{62} & \multirow{2}{*}{1.11} & \multirow{2}{*}{.27} \\
\hline & Kontrol Grubu & 34 & 55.4 & 28.7 & & & \\
\hline \multirow{2}{*}{ Başarı } & Deney Grubu & 30 & 18.6 & 4.89 & \multirow{2}{*}{62} & \multirow{2}{*}{2.36} & \multirow{2}{*}{$.02^{*}$} \\
\hline & Kontrol Grubu & 34 & 15.9 & 4.10 & & & \\
\hline
\end{tabular}

$$
\mathrm{p}<.05
$$

Tablo 4 incelendiğinde, deney ve kontrol gruplarının, FKÖ ve FÖYMÖ son test puanları arasında anlamlı bir farkın olmadığ ${ }^{\prime}(\mathrm{p}>0.05)$, YEÜABT son test puanları arasında anlamlı bir farkın olduğu belirlenmiştir. Bu bulgulara göre, uygulanan Jigsaw IV tekniğinin fen motivasyon ve fen kaygı düzeylerine istatiksel olarak etki etmediği; buna karşın tekniğin akademik başarıyı arttırdı ğ 1 istatiksel olarak tespit edilmiştir.

Tablo 5'te deney grubu öğrencilerin YEÜABT, FKÖ, FÖYMÖ ön test-son testinden aldıkları puanların " $t$-testi" analiz sonuçları verilmiştir.

Tablo 5. Deney Grubundaki Öğrencilerin YEÜABT, FKÖ, FÖYMÖ Ön Test-Son Test Puanlarına İlişkin $t$-testi Sonuçları

\begin{tabular}{|c|c|c|c|c|c|c|c|}
\hline & & $N$ & $\bar{X}$ & $s$ & $s d$ & $t$ & $p$ \\
\hline \multirow{2}{*}{ Motivasyon } & Ön Test & 30 & 1.24 & 14.9 & \multirow{2}{*}{29} & \multirow{2}{*}{0.90} & \multirow{2}{*}{.37} \\
\hline & Son Test & 30 & 1.26 & 18.7 & & & \\
\hline \multirow{2}{*}{ Kayg1 } & Ön Test & 30 & 56.6 & 25.2 & \multirow{2}{*}{29} & \multirow{2}{*}{2.05} & \multirow{2}{*}{.04} \\
\hline & Son Test & 30 & 48.1 & 23.1 & & & \\
\hline \multirow{2}{*}{ Başarı } & Ön Test & 30 & 9.33 & 3.00 & \multirow{2}{*}{29} & \multirow{2}{*}{11.1} & \multirow{2}{*}{$.00^{*}$} \\
\hline & Son Test & 30 & 18.6 & 4.89 & & & \\
\hline
\end{tabular}

Tablo 5 'te verilen analiz sonuçlarına göre deney grubunun FÖYMÖ ön test-son test sonuçlarının istatistiksel olarak 0.05 düzeyinde anlamlı olmadığ belirlenmiştir $(\mathrm{t}=0.90, \mathrm{p}=.371) . \mathrm{Bu}$ sonuçlara göre uygulanan Jigsaw IV tekniğinin öğrencilerin fen öğrenmeye yönelik motivasyonları üzerinde bir etkisi olmadığı saptanmıştır.

Deney grubunun fen kaygısı ve akademik başarı ön test-son test sonuçları arasındaki fark her iki değişken için de 0.05 düzeyinde anlamlı bulunmuştur $(\mathrm{p}<.05)$. Tabloda yer alan aritmetik ortalamalar incelendiğinde, Jigsaw IV tekniğinin öğrencilerin fen kaygı düzeyini azalttığı, akademik başarı düzeyini ise artırdığı söylenebilir.

Tablo 6'da Kontrol grubu öğrencilerin YEÜABT, FKÖ, FÖYMÖ ön test-son testinden aldıkları puanların " $t$-testi" analiz sonuçları verilmiştir.

Tablo 6. Kontrol Grubundaki Öğrencilerin YEÜABT, FKÖ, FÖYMÖ Ön Test-Son Test Puanlarına İlişkin $t$-testi Sonuçları 


\begin{tabular}{|c|c|c|c|c|c|c|c|}
\hline & & $N$ & $\bar{X}$ & $s$ & $s d$ & $t$ & $p$ \\
\hline \multirow{2}{*}{ Motivasyon } & Ön Test & 34 & 1.24 & 13.22 & \multirow{2}{*}{33} & \multirow{2}{*}{0.42} & \multirow{2}{*}{.67} \\
\hline & Son Test & 34 & 1.25 & 20.73 & & & \\
\hline \multirow{2}{*}{ Kayg1 } & Ön Test & 34 & 59.29 & 30.68 & \multirow{2}{*}{33} & \multirow{2}{*}{0.62} & \multirow{2}{*}{.53} \\
\hline & Son Test & 34 & 55.37 & 28.73 & & & \\
\hline \multirow{2}{*}{ Başarı } & Ön Test & 34 & 8.09 & 3.42 & \multirow{2}{*}{33} & \multirow{2}{*}{8.37} & \multirow{2}{*}{$.00^{*}$} \\
\hline & Son Test & 34 & 15.94 & 4.10 & & & \\
\hline
\end{tabular}

Kontrol grubuna uygulanan geleneksel öğretim yönteminin öğrencilerin fen öğrenmeye yönelik motivasyon, fen kaygısı ve başarı düzeylerindeki değişimi belirlemek amacıyla yapılan t-testi sonuçlarına göre; başarı değişkeni açısından farklılaşmanın 0.05 düzeyinde olduğu tespit edilirken; diğer değişkenler açısından anlamlı bir farkın olmadığg görülmektedir. Eldeki veriler göstermektedir ki geleneksel öğretim yöntemlerinin öğrencilerin fen öğrenmeye yönelik motivasyon ve fen kaygısı düzeylerine etkisi istatistiksel olarak anlamlı değilken; akademik başarıyı arttırmaya yönelik etkisi istatistiksel olarak anlamlıdır.

\section{Sonuç ve Tartışma}

$\mathrm{Bu}$ araştırmada, Jigsaw IV tekniğinin öğrencilerin fen ve teknoloji dersine karş1 isteklendirme ve kaygı düzeyleri ile başarılarına etkisi yarı deneysel desen yöntemiyle incelenmiştir. Deneysel işlemden önce deney ve kontrol grubuna uygulanan FÖYMÖ testleri arasında anlamlı bir fark bulunamamıştır. Aynı şekilde, deneysel işlem sonrasında uygulanan son test sonuçları, iki grup arasında farklılaşma olmadığını göstermektedir. Bir başka deyişle, Jigsaw IV tekniği ile uygulanan geleneksel öğretim yöntemlerinin öğrencilerin fen öğrenimine yönelik motivasyon düzeyine etkisi benzer düzeydedir. Deney ve kontrol gruplarının ön test ve son test sonuçları karşılaştırıldığında, her iki grupta da deneysel işlem sonrasında katılımcıların motivasyon puanlarının artmasına rağmen bu artışın istatistiksel olarak anlamlı olmadığı görülmüştür. Literatürde Jigsaw tekniklerinin motivasyon üzerinde etkisi olmadığını ortaya koyan benzer çalışmalar yer almaktadır (Shackar, \& Fischer, 2004; Ayna, 2009). Bulguların tersine işbirlikli öğrenme yöntemi tekniklerinin motivasyonu artırdığını gösteren çalışmalar da yer almaktadır (Conrad, 1994; Hanze, \& Berger, 2007).

Geleneksel öğretim yöntemlerine alışkın öğrencilerin işbirliğine hazır olmaması ve yönteme yabancı olmaları, gruplar içinde sosyal becerileri gelişmemiş öğrencilerin yer alması, işbirlikli öğrenme yöntemlerinde öğrencilerin iş yükünün artması, mini sınav ve sınavların sıcça tekrarlanması gibi nedenler motivasyon düzeyinde değişiklik olmamasının sebebi olarak gösterilebilir (Ayna, 2009; Arslan, 2012).

Deneysel işlemden önce deney ve kontrol grubunda uygulanan fen kaygı ölçeği puanları arasında anlamlı bir fark bulunamamıştır. Uygulama sonrasında her iki grup için kaygı puan ortalamalarının azaldığı ve bu azalışın deney grubu için kontrol grubundan daha fazla olduğu tespit edilmiştir. Ancak iki grup arasındaki bu puan farkı istatistiksel olarak anlamlı değildir. $\mathrm{Bu}$ tespit, deney grubunda uygulanan Jigsaw IV tekniği ile geleneksel öğretim yöntemlerinin öğrencilerin kaygı düzeylerini azaltmada, benzer düzeyde etkili olduğunu ortaya koymaktadır. Ancak, deney ve kontrol gruplarının aynı test için ön test-son test sonuçlarına bakıldığında, Jigsaw tekniğinin uygulandığı deney grubunun ön test-son test puanları arasındaki fark istatistiksel olarak anlamlı bulunmuş, geleneksel öğretim yönteminin uygulandığı kontrol grubunun ön test- 
son test puanları arasındaki fark istatistiksel olarak anlamlı bulunmamıştır. Bu sonuçlardan yola çıkarak Jigsaw IV tekniğinin öğrencilerin fen kaygı düzeyini azalttığı söylenebilir.

İşbirlikli öğrenme yöntemlerinin fen kaygısı üzerine etkisini araştıran benzer çalışmalar oldukça azdır. Bununla birlikte farklı alan ve derslerde işbirlikli öğrenme tekniklerinin derse yönelik kaygı düzeyini azalttı̆̆ını gösteren çalışmalar yer almaktadır (Betz, 1978; Oludipe, \& Awokoy, 2010; Lavasani, \& Khandan, 2011; Doğru, 2012). Geleneksel öğretim yöntemlerinin aksine her türlü hata, yanlış öğrenme ve sorumluluk bireysel olarak değil, grup olarak değerlendirildiğinden bireyin hata yapma korkusu azaldığı için, Jigsaw uygulaması sonrasında bireylerin kaygı düzeyi azalmış olabilir (Oludipe, \& Awokoy, 2010).

Deneysel işlemden önce deney ve kontrol grubunda uygulanan başarı testleri arasında anlamlı bir fark yokken, uygulama sonrasında iki grup arasındaki farkın deney grubu lehine anlamlı olduğu tespit edilmiştir. Bu tespit, deney grubunda uygulanan Jigsaw IV tekniğinin öğrencilerin başarılarını artırmada, geleneksel öğretim yöntemine göre daha etkili olduğunu ortaya koymaktadır. Bu bulgular alan yazınındaki Jigsaw tekniklerinin kullanıldığı diğer çalışmalarla da desteklenmektedir (Theodora, 2001; Doymuş, \& Şimşek, 2007; Dollard, \& Mahoney, 2010; Özkıdık, 2010; Sanc1, 2011).

\section{KAYNAKÇA}

Açıkgöz, K. Ü. (2006). Aktif Öğrenme. İzmir: Biliş.

Aksoy, G. (2006). İşbirlikçi öğrenme yönteminin genel kimya laboratuarı dersinde akademik başarıya, laboratuar malzemesi tanıma ve kullanma becerisine etkisi. Yayımlanmış Yüksek Lisans Tezi. Atatürk Üniversitesi, Fen Bilimleri Enstitüsü, Erzurum.

Anderson, F. J., \& Palmer, J. (1988). "The jigsaw approach: Students motivating students". Education, $109(1), 59-62$.

Arık, A. (1996). Motivasyon ve Heyecana Giriş. İstanbul: Çantay Kitabevi.

Arslan, A. (2012). "Sözcük Türleri Öğretiminde Jigsaw Tekniğinin Etkisi”. DPUJSS, 1 (32), 157-68.

Aydede, M. N., \& Matyar, F. (2009). Fen bilgisi öğretiminde aktif öğrenme yaklaşımının bilişsel düzeyde öğrenci başarısına etkisi. Türk Fen Eğitimi Dergisi, 6 (1), 115-27.

Ayna, C. (2009). Fen ve Teknoloji Dersinde Birleştirme II (Jigsaw II) Yönteminin Kullanılmasinin ve Sosyo-Ekonomik Düzeyin Öğrencilerin Akademik Başarı, Fen ve Teknoloji Dersine Yönelik Tutum ve Motivasyon Düzeylerine Etkisi. Yayınlanmış Yüksek Lisans Tezi. Zonguldak Karaelmas Üniversitesi, Sosyal Bilimler Enstitüsü, Zonguldak.

Betz, N. E. (1978). "Prevalence, Distribution and Correlates of Math Anxiety in College Students". Journal of Conseling Psychology, 25 (5), 441-48.

Buzludağ, P. (2010). 6. Sinıf Fen ve Teknoloji Dersi “Canlılarda Üreme, Büyüme ve Gelişme” Ünitesinin İşbirlikli Öğrenmeyle (Jigsaw Tekniği) Öğretiminin Öğrenci Başarısına Etkisi. Yayınlanmış Yüksek Lisans Tezi. Frrat Üniversitesi, Fen Bilimleri Enstitüsü, Elazı ğ.

Büyüköztürk, Ş. (2006). Sosyal Bilimler İçin Veri Analizi El Kitabı. Ankara: Pegem A Yayıncılık.

Conrad, L. M. (1994). "Student Motivation and cooperative learning". N/A. Kaynak: http://www.eric.ed. gov/PDFS/ED407128.pdf, (Erişim: 11.05.2012).

Demirel, Ö. (2008). Öğretim Illke ve Yöntemleri: Öğretme sanatı. Ankara: Pegem A Yayınc1lık.

Doğru, E. (2012). Matematik Öğretiminde Kullanılan Ayrllıp Birleşme Tekniğinin Öğrencilerin Özyeterlik, Kaygı ve Kalıcllık Düzeylerine Etkisi. Yayınlanmış Yüksek Lisans Tezi. Akdeniz Üniversitesi, Sosyal Bilimler Enstitüsü, Antalya.

Dollard, M. W., \& Mahoney, K. (2010). "How Effective is the Jigsaw Method When Used to Introduce New Science Curricula in Middle School Science". Ontario Action Researcher, 10 (3), 50-64.

Doymuş, K., \& Şimşek, Ü. (2007). "Kimyasal Bağların Öğretilmesinde Jigsaw Tekniğinin Etkisi ve Teknik Hakkında Öğrenci Görüşleri”. Milli Eğitim Dergisi, 173 (1), 231-43. 
Güzeller, O. C., \& Doğru, M. (2011). "Development of Science Anxiety Scale for Primary School Students". Social Indicators Research, 507-518. doi:10.1007/s11205-011-9894-6.

Hanze, M., \& Berger, R. (2007). "Cooperative Learning, Motivational Effects, and Student Characteristics: An Experimental Study Comparing Cooperative Learning and Direct Instruction in $12^{\text {th }}$ Grade Physics Classes". Learning and Instruction, 17 (1), 29-41.

Hedeen, T. (2003). "The Reverse Jigsaw: A Process of Cooperative Learning and Discussion". Teaching Sociology, 31(3), 325-32. http://www.jstor.org/stable/3211330?seq=2, (Erişim: 09.02.2012).

Holliday, D. C. (2000). "The development of in a secondary social studies classroom". N/a. Kaynak: http://www.eric.ed.gov/contentdelivery/servlet/ERICServlet?accno=ED447045, (Erişim: 01.05.2012).

Holliday, D. C. (2002). "Jigsaw IV: using student/teacher concerns to improve jigsaw 111". N/A. Kaynak: http://eric.ed.gov/pdfs/ed465687.pdf, (Erişim: 09.02.2012)

Johnson, D., \& Johnson, R. (1975). Learning Together and Alone: Cooperation, Competition, and Individulization. Englewood Cliffs, $\mathrm{Nj}$ : Prentice Hall.

Johnson, D. W., Johnson, R.T., \& Smith, K. A. (1998). "Cooperative Learning Returns to College: What Evidence is There That It Works?". Change, 30 (4), 26-35.

Kalem, S., \& Fer, S. (2003). "Aktif öğrenme modeliyle oluşturulan öğrenme ortamının öğrenme, öğretme ve iletişim sürecine etkisi”. Kuram ve Uygulamada Eğitim Bilimleri, 3 (2), 433-61.

Kılıç, D. (2008). "The Effect of the Jigsaw Technique on Learning the Concepts of the Principles and Methods of Teaching”. World Applied Sciences Journal, 4 (1), 109-14.

Lavasani, M. G., \& Khandan, F. (2011). "Mathematic Anxiety, Help Seeking Behavior and Cooperative Learning". Cypriot Journal Of Educational Sciences, 6 (2), 61-74.

Oludipe, D., \& Awokoy, O. J. (2010). "Effect of Cooperative Learning Teaching Strategy on the Reduction of Students' Anxiety for Learning Chemistry”. Türk Fen Eğitim Dergisi, 7 (1), 1-36.

Özel, M. (2004). "Başarılı Bir Fizik Eğitimi İçin Stratejiler". Pamukkale Üniversitesi Eğitim Fakültesi Dergisi, 16, 79-88.

Özkıdık, K. (2010). Illköğretim 7. Sınıf Fen ve Teknoloji Dersi Yaşamımızdaki Elektrik Ünitesinin Öğretiminde İşbirlikli Öğrenme Yönteminin Öğrenci Başarısına ve Tutuma Etkisi. Yayımlanmış Yüksek Lisans Tezi. Gazi Üniversitesi Eğitim Bilimleri Enstitüsü, Ankara.

Sancı, M. (2011). Illköğretim 4. Sinıf Fen ve Teknoloji Dersi Öğretiminde Uygulanan Jigsaw ve Grup Araştırması Tekniklerinin Öğrencilerin Akademik Başarıları Üzerine Etkisi. Yayımlanmış Yüksek Lisans Tezi. Atatürk Üniversitesi, Eğitim Bilimleri Enstitüsü, Erzurum.

Senemoğlu, N. (2011). Gelişim, Öğrenme ve Öğretim. Ankara: Pegem Akademi.

Shackar, H., \& Fischer, S. (2004). "Cooperative learning and the achievement of motivation and perceptions of students in 11th grade chemistry classes". Learning And Instruction, 14 (1), 69-87.

Sivan, A., Leung, R. W., Woon, C. C., \& Kember, D. (2000). "An implementation of active learning and its affect on quality of student learning". Inovations in Education and Training International, 37 (4), 381-89.

Slavin, R. E. (1991). "Student Team Learning”. N/A. Kaynak:http://www.eric.ed.gov/PDFS/ED260023 pdf, (Erişim: 17.02.2012).

Şimşek, Ü. (2007). Çözeltiler ve Kimyasal Denge Konularında Uygulanan Jigsaw ve Birlikte Öğrenme Tekniklerinin Öğrencilerin Maddenin Tanecikli Yapıda Öğrenmeleri ve Akademik Başarıları Üzerine Etkisi. Yayımlanmış Doktora Tezi. Atatürk Üniversitesi Fen Bilimleri Enstitüsü, Erzurum.

Theodora, D., P. (2001). "The Effectiveness of Jigsaw Cooperative Learning on Students' Achievement and Attitudes Toward Science". Science Education International, 12 (4), 6-11.

Thousand, J., Villa, A., \& Nevin, A. (2009). An Overview of Cooperative Learning. Baltimore, MD: Brookes Press. Kaynak: http://www.co-operation.org/pages/overviewpaper.html, (Erişim: 10.02.2012).

Ünlü, S. (2001), Psikoloji. Eskişehir: Anadolu Üniversitesi, Açık Öğretim Fakültesi Yayınları.

Yılmaz, H., \& Çavaş, P. (2007). "Reliability and Validity Study of the Students' Motivation Toward Science Learning (smtsl) Guestionnaire". Illkögretim Online, 6 (3), 430-40. 